\title{
PREGLED DIMENZIONIRANJA PELTONOVE TURBINE
}

\author{
PELTON TURBINE DESIGN OVERVIEW
}

\author{
Ivana Sušanj Čule*, Doris Vračevićc*, Nevenka Ožanić ${ }^{*}$
}

\begin{abstract}
Sažetak
Unutar ovoga rada biti će dan pregled dimenzioniranja Peltonove turbine. Kako se pri radu turbine javljaju vrlo složeni uvjeti tečenja i fizikalni procesi, optimizacija $i$ samo dimenzioniranje ovakvog sustava je izazov. Primjerice, u radu turbine javljaju se četiri režima tečenja: (i) stacionarno tečenje u uzvodnim i dovodnim cijevima, (ii) slobodni pad mlaza vode nakon izlaska s mlaznice, (iii) tečenje sa slobodnom vodnom površinom na lopaticama Peltonove turbine te (iv) raspršeno dvofazno tečenje na kućištu Peltonove turbine. S obzirom da postoji cijeli niz različitih formula i preporuka za dimenzioniranje, cilj ovoga rada bio je objediniti i dati pregled istih na jednom mjestu. Istraživanje za potrebe ovoga rada proizašlo je iz prethodnog istraživanja za potrebe izrade diplomskoga rada.
\end{abstract}

Ključne riječi: Pelton turbina, dimenzioniranje, mlaznica, Peltonovo okretno kolo, lopatica

\begin{abstract}
This paper presents an overview of Pelton turbine design. Since very complex flow conditions and physical processes occur during the operation of the turbine, the optimization and design of such a system is, consequently, a challenge. There are several different formulas and recommendations for design and optimization. Therefore, the aim of this paper was to consolidate them and give an overview in one place. The research for the purposes of this paper arose from the previous research for a master thesis.
\end{abstract}

Key words: Pelton turbine, design, nozzle, Pelton wheel, bucket

* Sveučilište u Rijeci, Građevinski fakultet, Radmile Matejčić 3, 51000 Rijeka E-mail: \{isusanj, nozanic\}@gradri.uniri.hr

** Sveučilište u Rijeci, Građevinski fakultet, Radmile Matejčić 3, 51000 Rijeka E-mail: dvracevic@student.uniri.hr 


\section{Uvod}

Energija vode jedan je od najznačajnijih izvora obnovljive energije i ekonomski najkonkurentniji fosilnim gorivima i nuklearnoj energiji. Energija, koju ima neka tekućina u strujanju određenom brzinom, sastoji se od potencijale i kinetičke energije te energije tlaka, a svaka od tih energija može se pretvoriti u korisni oblik uz pomoć strojeva za transformaciju energije.

Korištenje energetskog potencijala vode seže u daleku povijest, u doba kada su Grci i Rimljani, otprilike 100. godina prije Krista, koristili vodenička kola koja je pokretao tok rijeke ili potoka, kako bi pokretali mlinove za žito i kukuruz. Negdje u 1. stoljeću, vodenička kola počela su se koristiti i u Kini, gdje se njihova tehnologija nastavila razvijate. Znanja vezana za njih su nakon 13. stoljeća iz Kine postepeno opet prenesena u Europu. Sve veća primjena vodeničkih kola i njihov daljnji razvitak rezultirao je otkrićem vodne turbine, koja ih je krajem 19. stoljeća u potpunosti zamijenila. Vodne turbine jedan su od ključnih otkrića u razvoju hidroelektrana. Iako se kroz povijest energija vode koristila za navodnjavanje i pogon različitih naprava (vodenička kola, mlinovi, lučke dizalice i dizala, strojevi u tekstilnoj industriji i slično), danas se energija vode u najvećoj mjeri koristi u hidroelektranama, gdje se postupno preko raznih turbina i generatora dobiva električna energija [1].

Unutar ovoga rada biti će dan pregled dimenzioniranja Peltonova turbine. Naime, Peltonova turbina jedna je od prvo patentiranih turbina krajem 19. stoljeća, a način dimenzioniranja pojedinih dijelova turbine do dan danas za inženjere predstavlja izazov. Ne postoji unificirani način za dimenzioniranje Peltonove turbine, već čitav niz raznih preporuka i izračuna, što u praksi otežava odabir svih dimenzijskih parametara Peltonove turbine. Inženjeri i znanstvenici zbog toga preporučuju da se dimenzioniranje Peltonove turbine provodi kombinacijom matematičkog izračuna, upotrebom fizikalnih modela te kompjuterskim simulacijama.

Upravo zbog navedenih raznovrsnih pristupa dimenzioniranju Peltonove turbine, ovim će se radom pokušati obuhvatiti i dati pregled matematičkih izračuna pri njenom dimenzioniranju.

\section{Povijest razvoja Peltonove turbine}

\subsection{Izum Peltonove turbine}

Sve do kraja 19. stoljeća svi uobičajeni načini korištenja energije vode svodili su se na korištenje potencijalne energije vode, odnosno na kretanje vode koje je preko stroja (uobičajeno vodenica) proizvodila određeni rad. Kako je u to vrijeme bila u tijeku druga industrijska revolucija, potreba za razvojem novih načina pokretanja raznoraznih strojeva bila je prijeko potrebna. 


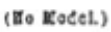

KNo. 409,866 .

110. $400,806$.

Patented Ang. 27, 1889.
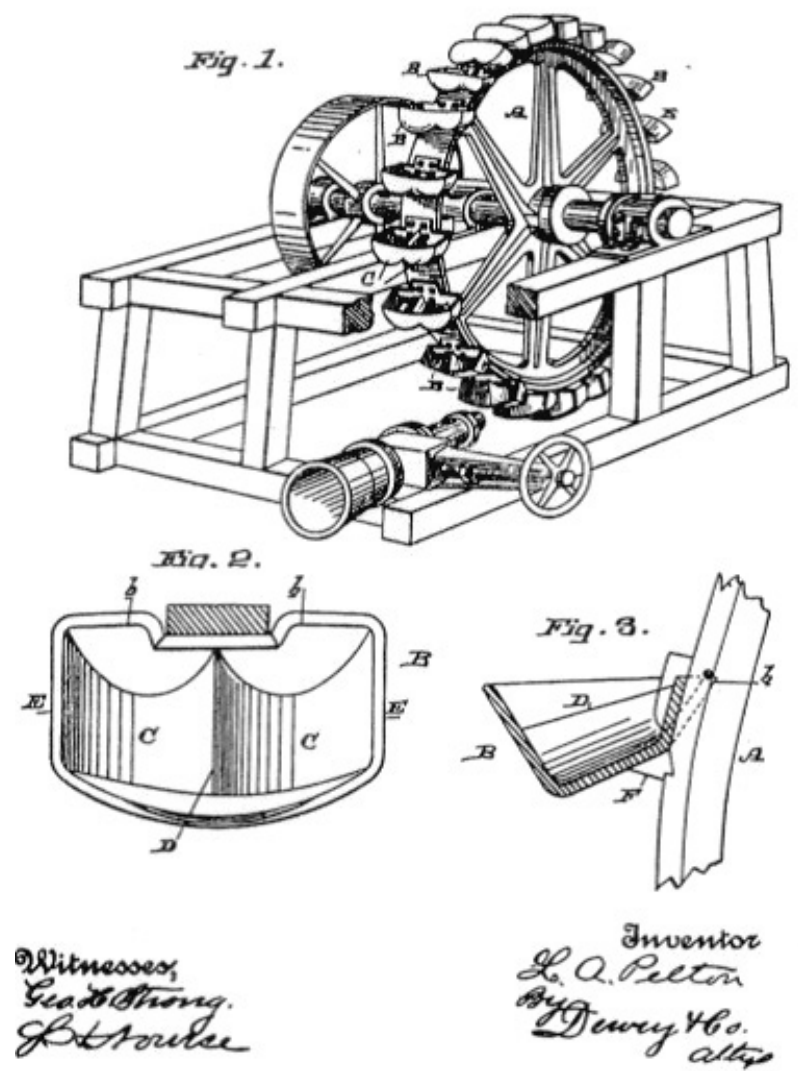

Slika 1. Preslika izvornog dokumenta patenta Peltonova turbina [2]

Razvoj Peltonove turbine veže se za rudarsku industriju i vrijeme zlatne groznice. Rudarska industrija zlata u Američkim Sjedinjenim Državama je u doba druge industrijske revolucije ovisila o parnim strojevima čije su potrebe za pogonskim gorivom, kao što su drvo i ugljen, bile enormno velike, što je motiviralo izumitelje da istražuju i druge pristupe dobivanja pogonske energije.

U Kaliforniji je graditelj mlinova Samuel Knight 1866. godine izumio stroj čiji je pogon radio na u potpunosti drugom principu od uobičajenih vodeničkih kola. Inspiriran mlaznim sustavima vode korištenima pri rudarenju i ispiranju u rudnicima zlata, Samuel Knight osmišljava prvu impulsnu turbinu. Knight razvija okretno kolo na kojem se nalaze takozvane lopatice, koje zahvaćaju energiju vode s mlaznica, dovedenu 
cjevovodom iz akumulacijskog prostora, čime je postignuta mogućnost mobilnosti sustava, te pretvorba značajne potencijalne energije vode $u$ kinetičku energiju[2].

Lester Allan Pelton je rođen 1829. godine u Vermillionu, u saveznoj državi Ohio. U vrijeme zlatne groznice, 1850. godine, seli u Kaliforniju te radi kao stolar i graditelj mlinova. U Kaliforniji upoznaje Samuela Knighta, zajedno s njim eksperimentira na novo osmišljenoj turbini te 1879. osmišljava turbinu $\mathrm{s}$ dvostrukim lopaticama. Usavršavanjem osnovnog oblika turbine eliminira gubitke energije Knightove turbine, razdjeljujući mlaz vode prema stranicama turbine [3]. Nakon deset godina rada na usavršavanju turbine, 1889. godine L.A. Pelton prijavljuje i patent impulsne turbine koju naziva L.A. Pelton vodeničko kolo, kao što je prikazano na Slici 1 [2].

\subsection{Moderna Peltonova turbina}

Izgled današnje Peltonove turbine možemo zahvaliti poboljšanjima koje je 1895. godine osmislio William Doble, koji je polucilindrične lopatice zamijenio eliptičnim oblikom lopatica s prorezom. Time je omogućio nadolazećem mlazu vode nesmetan ulazak na lopatice turbine [2].

Moderne Peltonove turbine danas proizvode i do 450 MW električne energije s velikim rasponom tlačne visine od 250 do $1900 \mathrm{~m}$, a njihova osovina može biti postavljena horizontalno (pri primjeni jedne do dvije mlaznice) te vertikalno (pri primjeni od dva do sedam mlaznica). Primjer Peltonove turbine s horizontalnom osovinom je prikazan na Slici 2, a na Slici 3 je prikazana Peltonova turbina s vertikalnom osovinom i četiri mlaznice [2].

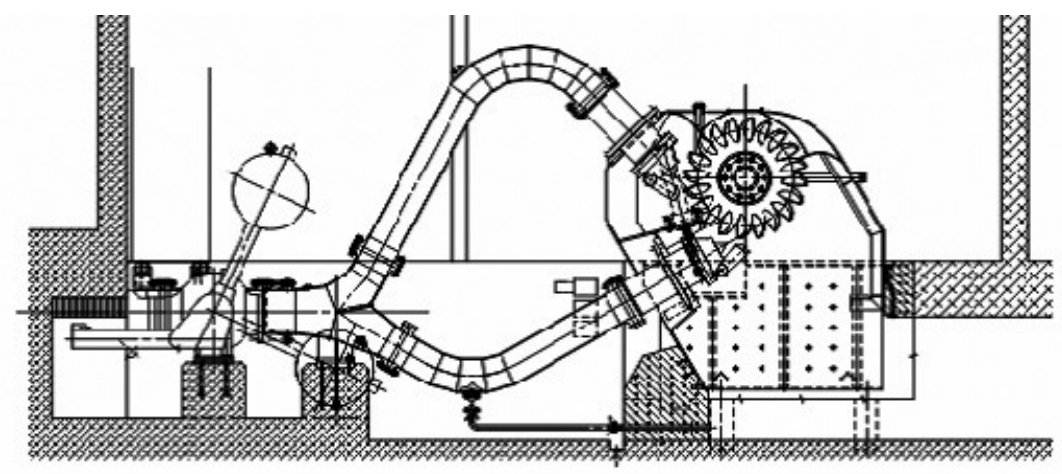

Slika 2. Peltonova turbina s horizontalnom osovinom i dvije mlaznice (modificirano prema: [4]) 


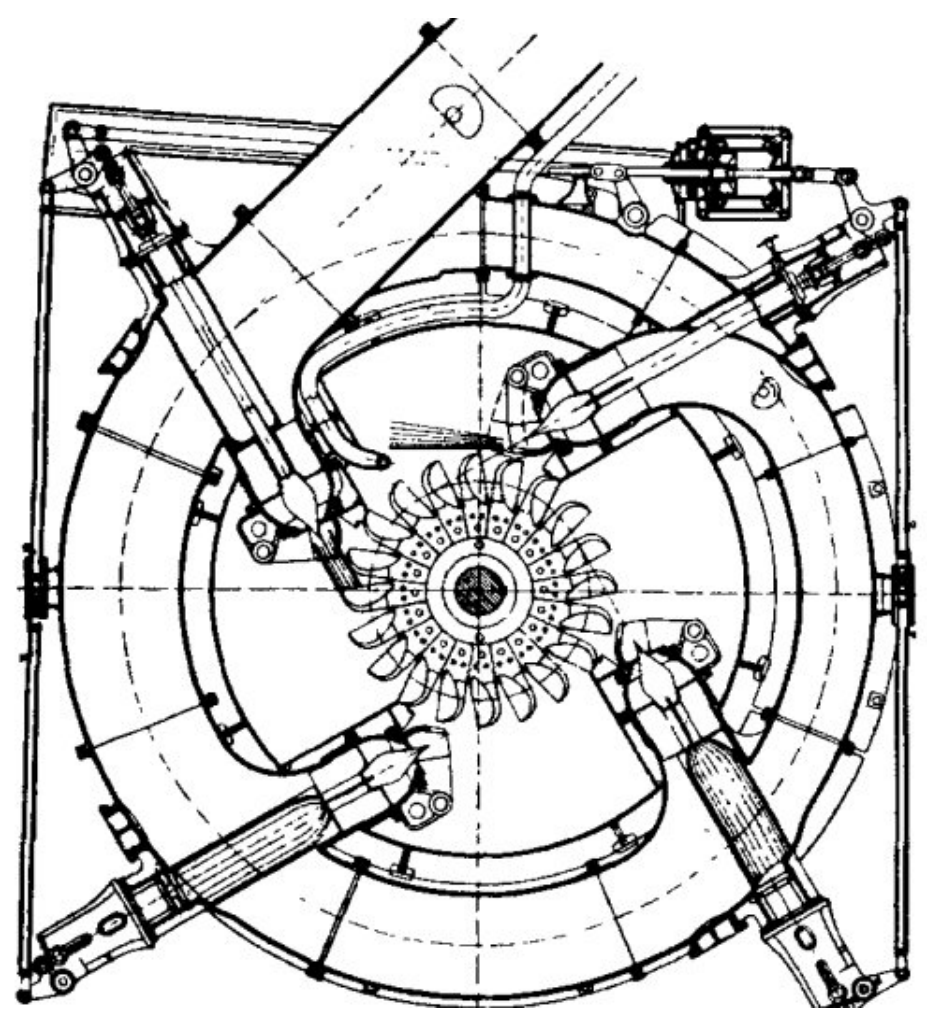

Slika 3. Slika 3. Peltonova turbina s vertikalnom osovinom i četiri mlaznice (modificirano prema: [5])

Peltonova turbina je jedna od najučinkovitijih impulsnih turbina koja proizvodi energiju koristeći zamah vode koji udara u lopatice postavljene na obodu [6, 7]. Pod utjecajem jake gospodarske konkurencije u industriji proizvodnje turbina, danas se kontinuirano radi na poboljšanjima $\mathrm{i}$ optimizaciji Peltonovih turbina, kao i na pronalaženju novih računalnih alata za analizu. Bez obzira na opsežna istraživanja na području optimizacije Peltonovih turbina i njezinoj širokoj primjeni, smjernice za dimenzioniranje se većinom temelje na opsežnim eksperimentalnim istraživanjima nastalim pristupom pokušaja i pogreške, a koje zbog visokih troškova sve više zamjenjuju i moderni numerički modeli [8].

\section{Dimenzioniranje Peltonove turbine}

Unutar ovoga poglavlja bit će opisani osnovni geometrijski dijelovi Peltonove turbine te razni računski pristupi njenog dimenzioniranja. 


\subsection{Osnovne geometrijske veličine Peltonove turbine}

Kao što je i ranije spomenuto, današnji izgled Peltonove turbine nastao je preinakama koje je u dizajnu turbine uveo William Doble. Osnovni dijelovi Peltonove turbine su lopatice, okretno kolo (rotor) i mlaznica (jedna ili više njih), koja se sastoji od regulatora i ventila, kao što je prikazano na Slici 4. Veličina okretnog kola, odnosno rotora je osnovno definirana njegovim mlaznim promjerom $D_{m^{\prime}}$ dok regulator i igličasti ventil u sklopu mlaznice definiraju debljinu dolaznog mlaza $d_{o}$ na lopatice.

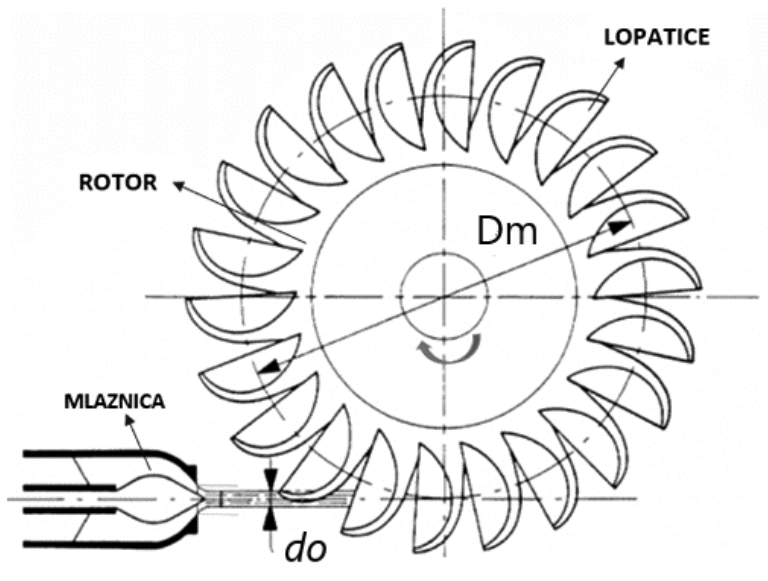

Slika 4. Shema Peltonove turbine (modificirano prema: [5])

Detaljniji geometrijski dijelovi okretnog kola Peltonove turbine prikazani su na Slici 5, pri čemu su definirani: (i) $R_{m}$ - polumjer okretnog kola, (ii) $R_{c}$ - polumjer okretnog kola od središta osovine do izreza na lopaticama, (iii) $R_{s}$ - polumjer okretnog kola od središta osovine do vršne točke razdjelnika lopatica, (iv) $R_{b}$ - polumjer okretnog kola od središta osovine do vršnog unutarnjeg ruba lopatice, (v) $R_{a}$ - ukupni polumjer okretnog kola i (vi) $r_{s}$ - polumjer osovine. 


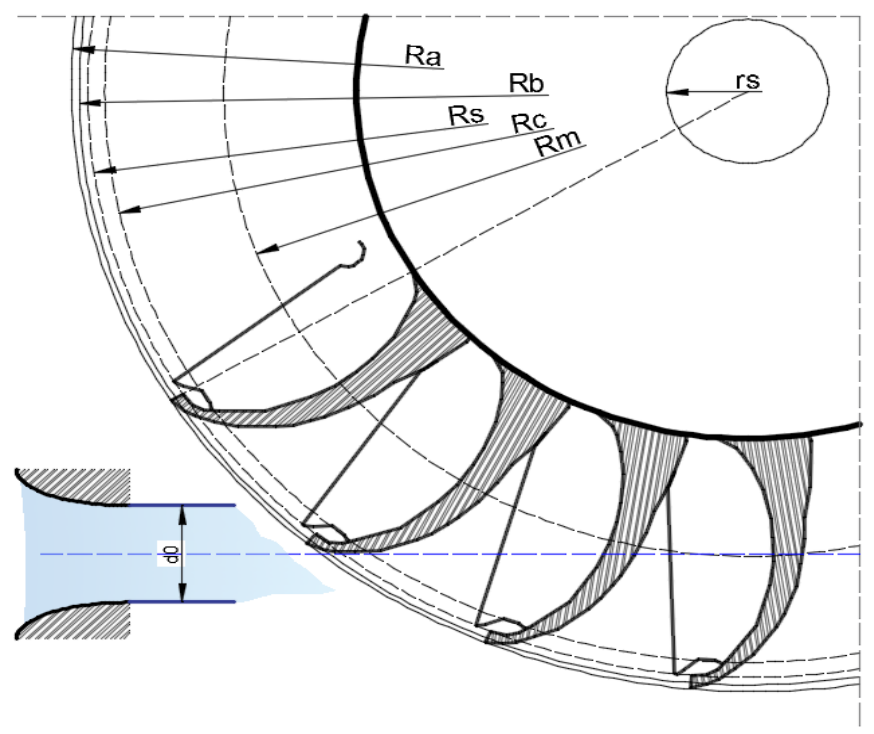

Slika 5. Geometrijski dijelovi okretnog kola Peltonove turbine (modificirano prema: [9])

Lopatice koje se nalaze na obodu kola definirane su svojim brojem $N$ te svojom geometrijom, kao što je prikazano na Slici 5. Geometrijski dijelovi lopatice definirani su kao: (i) $B_{a}$ - širina lopatice, (ii) $B$ - unutarnja širina lopatice, (iii) $B_{c}$ - širina izreza lopatice, (iv) $A$ - dužina lopatice, (v) $C$ dubina lopatice i $\beta_{2}$ - kut izlaza mlaza iz lopatice.
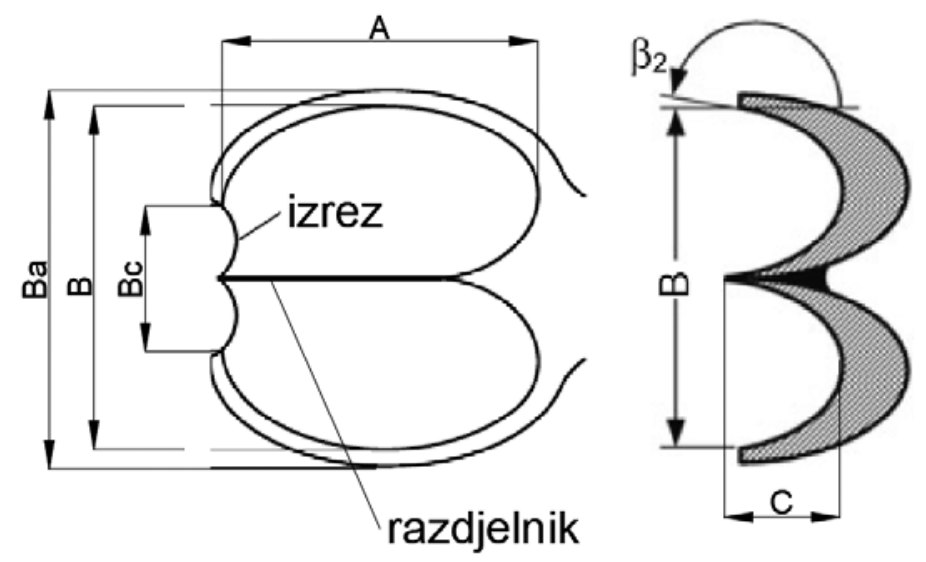

Slika 6. Geometrijski dijelovi lopatice Peltonove turbine (izradili autori prema: [9]) 
Mlaznica je sastavni i veoma važan dio Peltonove turbine, a sastoji se od dovodne cijevi te igličastog ventila s regulatorom. Geometrijski dijelovi mlaznice prikazani su na Slici 6, pri čemu su definirani kao: (i) $D_{0}$ - promjer otvora mlaznice, (ii) $\alpha_{N}$ - kut igličastog ventila $\left(\alpha_{N}=25^{\circ}\right)$, (iii) $\alpha_{D}-$ kut kontrakcije mlaza $\left(\alpha_{D}=25^{\circ}-45^{\circ}\right)$, (iv) $D_{N}$ - promjer igličastog ventila, (v) $D_{D}$ - promjer cijevi mlaznice i (vi) $d_{s}$ - promjer osovine igličastog ventila.

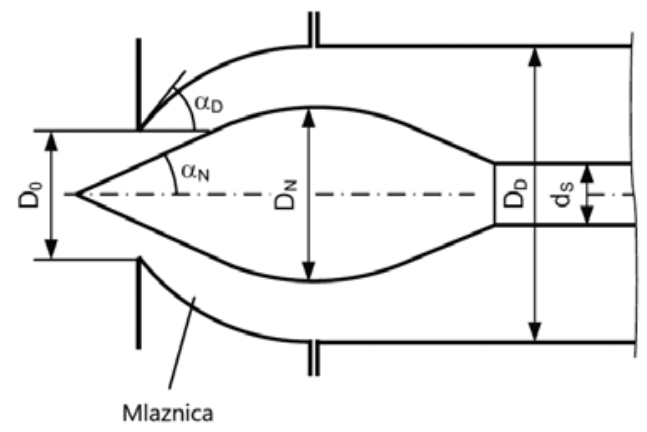

Slika 7. Geometrijski dijelovi mlaznice Peltonove turbine (modificirano prema: [9])

\subsection{Dimenzioniranje Peltonove turbine}

U velikom broju literature koja se bavi mehanikom fluida moguće je pronaći opća objašnjenja o uvjetima rada i pravilima dimenzioniranja za Peltonove turbine $[10,11,12,13,14,15,16]$. Bez obzira na važnost te dugu povijest razvoja i optimiziranja Peltonove turbine, gotovo nije moguće pronaći nekakav značajan pomak u dimenzioniranju i optimizaciji u usporedbi s izvornim oblikom turbine. S obzirom da fizikalni procesi koji se odvijaju pri radu Peltonove turbine još uvijek nisu u potpunosti razjašnjeni, praktično znanje i iskustvo projektanta dolazi do izričaja pri dimenzioniranju, a u tome im pomažu i fizikalni te matematički modeli. U nastavku rada biti će prikazane opće formule za dimenzioniranje Peltonove turbine te će biti dan pregled iskustvenih preporuka koje su nastale $\mathrm{u}$ sklopu raznih istraživanja [9].

\subsubsection{Izračun brzine i protoka vode na mlaznici Peltonove turbine}

Voda dovodnom cijevi dolazi do mlaznice. Brzina $v_{d 0}$ i protok vode $Q$ na izlazu iz mlaznice bitni su parametri za dimenzioniranje Peltonove turbine. Brzina vode $v_{d 0}$, uključujući lokalne gubitke na mlaznici je definirana 
izrazom (1), odnosno pretvorbom potencijalne u kinetičku energiju, gdje je: $C_{v}$ - koeficijent mlaznice [-], $g$ - ubrzanje polja sile teže $\left[\mathrm{m} / \mathrm{s}^{2}\right]$ te $H_{n}-$ visinski potencijal vode $[\mathrm{m}][17,18,19,20]$ :

$$
v_{d_{0}}=C_{v} \sqrt{2 g \cdot H_{n}}
$$

Vrijednost koeficijenta mlaznice $C_{v}$ definiran je istraživanjima te je njegova vrijednost definirana u rasponu od $C_{v}=0,95-0,99$, ovisno o autorima $[17,18,21]$.

Protok vode $Q$ na izlazu iz mlaznice definiran je izrazom (2), gdje je: $A_{d o}$ - protočna površina mlaza vode $\left[\mathrm{m}^{2}\right], v_{d 0}$ - brzina vode na izlazu iz mlaznice $[\mathrm{m} / \mathrm{s}]$ te $n$ - broj mlaznica.

$$
Q=A_{d_{0}} \cdot v_{d_{0}} \cdot n
$$

\subsubsection{Tangencijalna brzina Peltonove turbine}

Brzina okretaja lopatica $U$ Peltonove turbine, odnosno tangencijalna brzina okretnog kola nastala udarom mlaza vode na lopatice, računa se prema izrazu (3), gdje je $K_{u}$-obodni koeficijent brzine [-]:

$$
U=K u \cdot \sqrt{2 \cdot g \cdot H_{n}}
$$

Obodni koeficijent brzine $K_{u}$ je jedan od najvažnijih parametara pri dimenzioniranju Peltonove turbine te predstavlja njezinu hidrauličku efikasnost [9], a utječe na smanjenje troškova pri proizvodnji. Preporučena vrijednost obodnog koeficijenta brzine razlikuje se temeljem različitih studija, pa se uzima u rasponu $K_{u}=0,45-0,48$ prema [9], dok je prema [17] taj raspon definiran u rasponu $K_{u}=0,44-0,46$, a prema $[23,21]$ najčešće korišteni obodni koeficijent brzine u praksi $K_{u}=0,46$. Nasir [19] primjerice navodi da bi se za maksimalnu učinkovitost turbine obodni koeficijent brzine trebao nalaziti u intervalu $K_{u}=0,46-0,47$. Širok raspon predloženih obodnih koeficijenata brzine svakako otežava optimizirano dimenzioniranje Peltonove turbine.

\subsubsection{Dimenzioniranje mlaznice Peltonove turbine}

Dimenzioniranje promjera mlaznice, odnosno potrebne debljine mlaza vode, zahtjevan je zadatak inženjera budući da je potrebno uzeti u obzir činjenicu da o debljini mlaza $d_{0}$ te kutu udara mlaza vode na lopatice turbine ovisi i njezina iskoristivost. Preporučljivo je da mlaz vode dolazi na lopatice turbine pod kutom između $1^{\circ}-3^{\circ}$ [17], nakon čega se na lopaticama mlaz vode putem razdjelnika dijeli na dvije strane te izlazi iz lopatica pod kutom od $\beta_{2}=165^{\circ}-175^{\circ}$ [22], dok je prema [17] raspon kuta definiran u 
granicama $\beta_{2}=165^{\circ}-170^{\circ}$. Dimenzioniranje promjera mlaznice moguće je izračunati na više načina, kao što je prikazano u nastavku.

Debljina mlaza $d_{0}$ na izlasku iz mlaznice se prema [18] računa primjenom izraza (1) i (2) uz prosječnu vrijednost koeficijenta mlaznice $C_{v}$ $=0,97$, kao što je prikazano izrazom (4):

$$
d_{0}=\frac{0,54}{H_{n}{ }^{1 / 4}} \cdot \sqrt{\frac{Q}{n}}
$$

S druge strane, Sabu i sur. [22] predlažu da se $d_{0}$ - debljina mlaza (m) računa prema izrazu (5) gdje je $D_{m}$ - promjer kola [m] $\left(D_{m}=2 R_{m}\right)$ :

$$
d_{0}=\frac{D_{m}}{10}
$$

Još jedan način izračuna debljine mlaza vode $d_{0}$ definiran je prema izrazu (6) [19, 23].

$$
d_{o}=\sqrt{\frac{4 \cdot Q}{n \cdot \pi \cdot v_{d o}}}
$$

\subsubsection{Dimenzioniranje promjera kola Peltonove turbine}

Dimenzioniranje promjera okretnog kola $D_{m}$ također nije jednoznačno određeno već se za izračun koriste različite formule nastale na temelju istraživanja.

Tako se prema [19] dimenzioniranje promjera okretnog kola $D_{m}$ temelji na maksimalnoj učinkovitosti turbine te se računa prema izrazu (7), gdje je $N$ - broj lopatica:

$$
D_{m}=38,6 \cdot \frac{\sqrt{H_{n}}}{N}
$$

Nigussie i sur. [18] primjerice za izraz (7) predlažu korištenje nešto manjeg koeficijenta, pa se dimenzioniranje promjera kola $D_{m}$ računa prema izrazu (8):

$$
D_{m}=37,7 \cdot \frac{\sqrt{H_{n}}}{N}
$$

Prema [22,20,23] se za dimenzioniranje promjera kola Peltonove turbine koristi nešto drugačiji izraz (9), koji ovisi o tangencijalnoj brzini $U$ :

$$
D_{m}=\frac{60 \cdot U}{N \cdot \pi}
$$




\subsubsection{Dimenzioniranje geometrije i broja lopatica Peltonove turbine}

Dimenzioniranje geometrijskog izgleda lopatice Peltonove turbine također nailazi na raznovrsne preporuke i načine koji svi ovise o širini mlaza vode $d_{0}$, pa će u Tablici 1 biti prikazane preporuke za izračun geometrije lopatice prema različitim autorima.

Tablica 1. Dimenzioniranje geometrije lopatice Peltonove turbine prema različitim autorima

\begin{tabular}{|c|c|c|c|c|c|}
\hline \multicolumn{6}{|c|}{ Geometrijski parametar lopatice } \\
\hline \multicolumn{2}{|c|}{$\begin{array}{c}A \\
\text { (visina lopatice) }\end{array}$} & \multicolumn{2}{|c|}{$\begin{array}{c}B \\
\text { (širina lopatice) }\end{array}$} & \multicolumn{2}{|c|}{$\begin{array}{c}C \\
\text { (dubina lopatice) }\end{array}$} \\
\hline Izraz: & Autor: & Izraz: & Autor: & Izraz: & Autor: \\
\hline$\underline{2,4} \cdot d_{0}$ & {$[22]$} & $\underline{2,6 \cdot d_{0}}$ & {$[22]$} & $\underline{0,9 \cdot d_{0}}$ & {$[22]$} \\
\hline $3,4 \cdot d_{0}$ & [19] & $3,4 \cdot d_{0}$ & $\begin{array}{l}{[19,20,} \\
23,24]\end{array}$ & $1,2 \cdot d_{0}$ & $\begin{array}{c}{[19,20,} \\
23,24]\end{array}$ \\
\hline $3,0 \cdot d_{0}$ & {$[20,23,24]$} & $\begin{array}{l}2,5 \cdot d_{0} \leq B \\
\leq 3,2 \cdot d_{0} \\
\end{array}$ & [21] & & \\
\hline $\begin{array}{l}2,1 \cdot d_{0} \leq A \\
\leq 2,7 \cdot d_{0}\end{array}$ & [21] & & & & \\
\hline
\end{tabular}

Mnoge studije obuhvaćene ovim radom usredotočene su na optimizaciju geometrije kola Peltonove turbine te na same mlaznice, dok se puno rjeđe istražuje učinak broja lopatica na korisnost turbine. Pa tako Židonis i sur. [8] primjerice ukazuju da prilagođavanje položaja i broja lopatica može uvećati učinkovitost turbine za 0,8\% (uz jednu mlaznicu), dok većina autora $[18,19,20,23,24]$ u svrhu izračuna broja lopatica $n$ upotrebljava izraz (10):

$$
n=\left(\frac{D_{m}}{2 \cdot d_{0}}+15\right)
$$

\section{Diskusija rezultata}

U pregledu formula koje se koriste pri dimenzioniranju glavnih geometrijskih veličina Peltonove turbine svakako je vidljiv velik raspon parametara koji se koriste u tu svrhu te u konačnici daju dimenzijski različite Peltonove turbine. S obzirom da se Peltonove turbine koriste s velikim rasponom tlačne visine od 250 do 1900 m, izazov čini odabir odgovarajućih koeficijenata kao što su koeficijent mlaznice $C_{v}$ i obodni koeficijent brzine $K_{u^{\prime}}$ pri izračunu osnovnih parametara. 
Kako pri dimenzioniranju Peltonove turbine treba uskladiti rad mlaznica te rotaciju turbine, već i male izmjene, primjerice širine mlaza $d_{0}$ i kuta udara mlaza na lopatice, čine značajnu razliku u njezinoj efikasnosti.

S druge strane, dimenzioniranje promjera kola $D_{m}$ nije uopće uvjetovano radom mlaznice i njezinim geometrijskim osobinama već po preporukama raznih autora ovisi o tlačnoj visini vode $H_{n}$ te broju lopatica $N$ na kolu, dok je oblik lopatica prema svim autorima uvjetovan širinom dolaznog mlaza vode $d_{0}$ na lopatice.

Budući da i za dimenzioniranje mlaznice, geometrije kola turbine te oblik lopatica postoji cijeli niz različitih formula koje su nastale raznim vrstama istraživanja, postavlja se pitanje primjenjivosti takvog pristupa. Naime, pri dimenzioniranju se inženjeri susreću s cijelim nizom raznih preporuka, što im svakako otežava posao.

\section{Zaključak}

Od kada je 1889. godine Peltonova turbina patentirana, pa do danas, cijeli niz znanstvenika i inženjera radi na usavršavanju i optimizaciji turbine kako bi njezina i ovako velika učinkovitost bila veća te kako bi se umanjili troškovi izgradnje i održavanja. Naime, s obzirom na vrlo složene uvjete tečenja i fizikalne procese koji se odvijaju u isto vrijeme i uz njihovu interakciju, razumijevanje i izračun ovakvoga sustava iznimno su zahtjevni. Kako se uvjeti tečenja na Peltonovim turbinama bitno razlikuju od drugih tipova turbina, javljaju se poteškoće i pri analitičkim opisima cjelokupnog procesa, a posebice pri određivanju snage turbine na temelju nestacionarnih parametara tečenja.

Za izračun osnovnih geometrijskih dimenzija mlaznice, kola i lopatica Peltonove turbine postoji čitav niz formula te preporuka za izračun, što svakako otežava posao odabira odgovarajućih dimenzija.

Na temelju svega navedenog, ne čudi činjenica da je dimenzioniranje Peltonove turbine zadatak koji iziskuje dugogodišnje iskustvo inženjera te primjenu fizikalnih i matematičkih modela.

Zahvala. Ovaj je članak rezultat rada u okviru dvaju projekta: Hidrologija vodnih resursa i identifikacija rizika od poplava i blatnih tokova na krškim područjima financiranog od strane Sveučilišta u Rijeci te Razvoj istraživačke infrastrukture na kampusu Sveučilišta u Rijeci (RC.2.2.06-0001), koji je financiran iz Europskog fonda za regionalni razvoj (EFRR) i Ministarstva znanosti, obrazovanja i sporta RH („,This paper has been supported in part by Ministry of Science, Education and Sports of the Republic of Croatia under the project Research Infrastructure for Campus-based Laboratories at the University of Rijeka, number RC.2.2.06-0001. The Project has been co-funded by the European Fund for Regional Development (ERDF)"). 


\section{Literatura}

[1] Renewable energy. https://ec.europa.eu/energy/topics/renewable-energy/ renewable-energy directive/overview en (1.7.2021.)

[2] Perrig, A. (2007). Hydrodynamics of the Free Surface Flow in Pelton Turbine Buckets. Doktorski rad. Lausanne. Švicarska: EPFL (ÉCOLE POLYTECHNIQUE FÉDÉRALE DE LAUSANNE)

[3] Doble, W. A. (1899) The Tangential Water-Wheel. Transactions of the American Institute of Mining Engineers, California Meetting 29, str. 852-894.

[4] Peron, M., Parkinson, E., Geppert, L., i Staubli, T. (2008) Importance of Jet Quality on Pelton Efficiency and Cavitation. U: International Conference on Hydraulic Efficiency Measurements. Milano, Italija: Water Energy Systems \& Tests, str. 1-9.

[5] Fulton, A. (1937) Present Tendencies in Water Turbine Machinery. Proceedings of the Institution of Mechanical Engineers 135(1), str. 387-444.

[6] Nechleba, M. (1957) Hydraulic Turbines: Their Design and Equipment. (engleski prijevod: C. Mayer i A.G. Evans) Prag, Čehoslovačka: Artia.

[7] Mosonyi, E. (1991) Water Power Development: High-head Power Plants. Budimpešta, Mađarska: Akademiai Kiado.

[8] Židonis, A. (2015) Optimisation and Efficiency Improvement of Pelton Hydro Turbine Using Computational Fluid Dynamics and Experimental Testing. Lancaster, Ujedinjeno Kraljevstvo: Lancaster University.

[9] Zhang, Z. (2016) Pelton Turbines. Swiss Federal Institute of Technology in Zurich. Zurich, Švicarska: Springer International Publishing.

[10] Thomann, R. (1931). Die Wasserturbinen und Turbinenpumpen: 2. Izdanje. Stuttgart, NJemačka: Wittwer-Verlag.

[11] Pfleiderer, C., i Petermann, H. (1986) Die Kennlinien ein-und mehrstufiger Maschinen unter Berücksichtigung der Dichteänderung. U: Strömungsmaschinen. Berlin, Njemačka: Springer. Vol 2, str. 527-542.

[12] Quantz, L., \& Meerwarth, K. (1963). Wasserkraftmaschinen: 11 Izdanje. Berlin, Njemačka: Springer - Verlag Berlin Heidelberg 1948.

[13] Bohl, W. (2004). Strömungsmaschinen 1: 9. Izdanje. Vogel Buchverlag.

[14] Menny, K. (2005) Strömungsmaschinen: 5. Izdanje. Teubner-Verlag.

[15] Giesecke, J., \& Mosonyi, E. (2005). Wasserkraftanlagen: 4. Izdanje. Berlin, Njemačka: Springer.

[16] Sigloch, H. (2006). Strömungsmaschinen: 3. Izdanje. Hanser Verlag.

[17] Atthanayake I. U., Sugathapala T., i Fernando R.(2011) Mathematical Model for the Effecton of Blade Friction on the Perfomance of Pelton Turbine, International Journal of Fluid Maachinery and Systems, 4(4), str. 396-409.

[18] Nigussie, T., Engeda, A., i Dribssa, E. (2017) Design, Modeling, and CFD Analysis of a Micro Hydro Pelton Turbine Runner: for the Case of Selected Site in Ethiopia. International Journal of Rotating Machinery, 2017. 
[19] Nasir B. A. (2013) Desing of High Efficiency Pelton Turbine For Micro - Hydropower Plant, International Journal of Electrical Engineering \& Technology, 2013, 4(1), str. 171-183.

[20] Ishola, F. A., Kilanko, O. O., Inegbenebor, A. O., Sanni, T. F., Adelakun, A. A., i Adegoke, D. D. (2019) Design and Performance Analysis of a Model Pico Size Pelton Wheel Turbine. Int. J. Civ. Eng. Technol.(IJCIET), 10(5), str.727-739.

[21] Eisenring, M. (1991). Micro Pelton Turbines. Harnessing Waterpower on a Small Scale. St. Gallen, Švicarska: Swiss Center for Appropriate Technology.

[22] Ebhota, W. S. (2017). Novel Domestic Design and Manufacturing of Pelton Turbine Bucket: a Key to Manage and Enhance Sub-Saharan Africa's Hydro Energy Potential. Doktorski rad. KwaZulu - Natal, JAR: University od KwaZulu - Natal.

[23] Sabu, S., George, N. J., Antony, T. A., i Alex, A. C. (2014) Design and Modelling of Pelton Wheel Bucket. International Journal of Engineering Research \& Technology, 3(3), str. 2278-0181.

[24] Manjunatha N., Kumar K., i Gowda T. (2016) Desing of a Pelton Wheel Turbine for a Micro Hydro Power Plant, International Journal of Innovative Research in Scince and Engineering, 2(7), str. 155-162. 